\title{
Questes
}

\section{Nuit, ennui, déduit dans Le Livre du Cuer d'Amours espris}

\section{Agathe Sultan}

\section{(2) OpenEdition}

1 Journals

\section{Édition électronique}

URL : http://journals.openedition.org/questes/1894

DOI : 10.4000/questes. 1894

ISSN : 2109-9472

\section{Éditeur}

Les Amis de Questes

\section{Édition imprimée}

Date de publication : 15 janvier 2004

Pagination : 15-20

ISSN : 2102-7188

\section{Référence électronique}

Agathe Sultan, « Nuit, ennui, déduit dans Le Livre du Cuer d'Amours espris », Questes [En ligne], 6 | 2004, mis en ligne le 01 janvier 2014, consulté le 15 septembre 2020. URL : http://journals.openedition.org/ questes/1894

Ce document a été généré automatiquement le 15 septembre 2020.

(c) Association des amis de «Questes » 


\title{
Nuit, ennui, déduit dans Le Livre du Cuer d'Amours espris
}

\author{
Agathe Sultan
}

NOTE DE L'ÉDITEUR

Cet article n'a pas encore fait l'objet d'une autorisation de publication.

INDEX

Keywords : Anjou, night, problem, dream, heart, sleep, journey, melancholy, dawn, twilight, iconography, painting, love, chivalry, naturalism, trial, storm, anxiety, nightmare, premonition, darkness, obscurity

Mots-clés : Anjou, nuit, ennui, songe, rêve, cœur, sommeil, voyage, mélancolie, aube, crépuscule, iconographie, peinture, chevalerie, naturalisme, épreuve, tempête, amour, inquiétude, cauchemar, prémonition, obscurité 